\title{
Effect of Serum and Serum Free Media on the Developmental Competence of OPU Derived Bovine IVP Embryo
}

\author{
Byung-Hyun Choi ${ }^{1,3}$, Bun-Young Park ${ }^{3}$, Rami Kong ${ }^{1,3}$, Mi-Ju Son ${ }^{3}$, Chan-Sang Park ${ }^{1,3}$, Nyeon-Hak Shin ${ }^{4}$, \\ Hye-Young Cheon ${ }^{4}$, Yeong-Rok Yang ${ }^{4}$, Jin-Woo Lee ${ }^{4}$, Jong-In Jin ${ }^{2,3}$ and Il-Keun Kong ${ }^{1,2, *}$ \\ ${ }^{1}$ Division of Applied Life Science (BK21 Plus), Gyeongsang National University, Jinju 52828, Korea \\ ${ }^{2}$ Institute of Agriculture and Life Science, Gyeongsang National University, Jinju 52828, Korea \\ ${ }^{3}$ GAST, Gyeongsang National University, Jinju 52828, Korea \\ ${ }^{4}$ Gyeongnam-do Provincial Government Livestock Research Institute, Sancheong 52263, Korea
}

Received December 4, 2019

Revised December 6, 2019

Accepted December 7, 2019

\section{*Correspondence}

II-Keun Kong

E-mail: ikong7900@gmail.com

ORCID

https://orcid.org/0000-0002-1906-9898
ABSTRACT Embryos produced with serum show the alterations in their ultrastructure, impaired compaction, abnormal blastulation, aberrant mRNA expression profiles and large calf syndrome with greater incidences of stillbirths and deaths after birth. The aim of the present study was to describe in vitro embryo production by analyzing embryo production, fetal production and pregnancy rate in free-serum medium. The OPU-IVP data used in this study from 2016. Approximately, sixteen cows (Hanwoo), which belonged to the Institute of Gyeongsang National University, were used. Two experimental group is used in this study. Serum groups were conducted in March to July and free-serum group was conducted in September to December. The recovered cumulus-oocyte complexes were morphologically classified to four grades based on the compaction of cumulus cells layers and homogeneity of the cytoplasm. The number of oocyte was significantly greater in serum groups than that in free-serum groups (29.61 \pm 0.63 vs. $15.6 \pm 0.62 ; p<0.05$ ). Between serum and free-serum groups indicate that average of 1 st and 2 nd grade oocytes were no difference ( $2.38 \pm 1.67$ vs. $2.38 \pm 1.48$; $p>0.05)$, but number of 3rd and 4th grade oocytes were greater in serum groups than that in free-serum groups $(7.31 \pm 7.64$ vs. $5.60 \pm 6.29 ; p<0.05)$. Embryo cleaved competence was higher in rate in free-serum groups than that in serum groups $(62.1 \%$ vs. 58.3; $p<0.05$ ). However, blastocyst developmental rate was no difference between serum and free-serum groups (33.1\% vs. 43.5\%; $p<0.05) .986$ recipients were used for embryo transfer. Pregnancy rate was indicated that between serum and free-serum group was no difference $(54.6 \%$ vs. $56.3 \% ; p<0.05)$. In conclusion, we developed the free-serum system for production of in vitro bovine embryos in order to meet the developmental and qualitative requirements for large scale commercial use.

Keywords: embryo development, free-serum, Korean native cow (Hanwoo), OPU

\section{INTRODUCTION}

In vitro culture of bovine embryos derived from in vitro maturation and fertilization (IVM-IVF) have succeeded in producing calves (Lu et al., 1987; Goto et al., 1988). An adequate in vitro culture system for bovine zygotes is re- 
quired for large-scale embryo production by IVM-IVF and genetic improvement by means of ovum pick-up (OPU) and IVM-IVF. Until now, the major obstacle associated with the extensive use of this technology is the lack of suitable methods to preserve in vitro produced embryos. Culturing of embryos results in fundamentally different embryos from those produced in vivo, particularly for ruminants (Lonergan et al., 2001; 2003). In vitro culture (IVC) media plays an important role in the development of in vitro fertilized embryos and have diverse compositions include defined media composed of simple salt solutions or undefined complex culture media supplemented with serum and with undefined components (Lane et al., 2007). Serum has been widely added to culture media because it contains embryotrophic factors and substances beneficial for embryonic development, such as antioxidants, growth factors, and heavy metal chelators (Murakami et al., 2011), and provides nutrients necessary for cell survival and proliferation (Wirthensohn and Barth, 1985). Although the role of serum is not completely known (for review, see (Thompson et al., 2007) it has been demonstrated that serum has a biphasic effect inhibiting early cleavage divisions and accelerating the development of morula and blastocysts (Van Langendonckt et al., 1997; Lonergan et al., 1999). It is also expected that serum provides energy substrates, amino-acids, vitamins, growth factors and heavy-metal chelators at concentrations that vary among batches (Pinyopummintr and Bavister, 1994). A higher development rate to the blastocyst stage is obtained from media supported with serum, but the serum effectiveness for the vitro embryo production might change considerably from one batch to another (Van Langendonckt et al., 1997). Furthermore, embryos produced with serum show alterations in their ultrastructure, impaired compaction, abnormal blastulation, aberrant mRNA expression profiles and large calf syndrome with greater incidences of stillbirths and deaths after birth (Van Langendonckt et al., 1997; Holmet et al., 1999; Wrenzycki et al., 2004). Moreover, bovine-derived sera or proteins have recently been avoided especially in human in vitro production systems because of the appearance of bovine spongiform encephalopathy and a viral or prion contamination risk. In addition to increasing the sensitivity to cryopreservation, serum enhances potential sanitary risks due to viruses, prions or mycoplasma contaminations, and is suspected to contribute to the large offspring syn- drome described in ruminants derived from IVP embryos (Jacobsen et al., 2000; Farin, 2001). It is also responsible for various alterations of embryo morphology, ultrastructure and kinetics of development (Van Langendonckt, 1997; Abe et al., 1999). Moreover, serum could act as antioxidant or prooxidant, depending on its constituents, which could also affect the cryoresistance of the embryos (Rizos et al., 2003). Taken together, these data indicate that a whole free-serum system for the production of IVP embryos is desirable.

The aim of the present study was to describe in vitro embryo production by analyzing embryo production, fetal production and pregnancy rate in free-serum medium.

\section{MATERIALS AND METHODS}

\section{Experimental animals}

The OPU-IVP data used in this study from 2016. Sixteen Korean native cows (Hanwoo) approximately, which belonged to the Institute of Agriculture and Life Science, Gyeongsang National University, were used. Study based on 2 experimental groups. Donor is equivalent. Serum group for March to July and free-serum group for September to December.

\section{Oocyte collection and in vitro maturation (IVM)}

OPU derive oocyte is (TCM-199) supplemented with $10 \%$ (v/v) FBS (Gibco BRL, Life Technologies, Grand Island, NY, USA), $1 \mu \mathrm{g} / \mathrm{mL}$ estradiol- $17 \beta, 10 \mu \mathrm{g} / \mathrm{mL}$ follicle-stimulating hormone, $10 \mathrm{ng} / \mathrm{mL}$ epidermal growth factor, 0.6 $\mathrm{mM}$ cysteine, and $0.2 \mathrm{mM}$ sodium pyruvate. Thereafter, groups of up to 50 COCs were transferred to a 4-well dish (Thermo Fisher Scientific, Waltham, MA, USA) containing $500 \mu \mathrm{L}$ IVM medium and incubated in a humidified atmosphere of $5 \% \mathrm{CO}_{2}$ in air at $38.5^{\circ} \mathrm{C}$ for $22-24 \mathrm{~h}$.

\section{In vitro fertilization (IVF) and IVC}

In vitro matured COCs were fertilized with frozenthawed bovine sperm that had been previously tested for IVF as described by Mesalam et al., 2017. Semen was thawed at $39^{\circ} \mathrm{C}$ for $1 \mathrm{~min}$, sperm were washed and pelleted in D-PBS by centrifugation at $750 \times \mathrm{g}$ for $5 \mathrm{~min}$ at room temperature, and motile sperm were recovered. The pellet was resuspended in $500 \mu \mathrm{L}$ heparin $(20 \mu \mathrm{g} /$ $\mathrm{mL}$ ) prepared in IVF medium Tyrode's lactate solution supplemented with $6 \mathrm{mg} / \mathrm{mL}$ bovine serum albumin (BSA), 
$22 \mathrm{mg} / \mathrm{mL}$ sodium pyruvate, $100 \mathrm{IU} / \mathrm{mL}$ penicillin, and $0.1 \mathrm{mg} / \mathrm{mL}$ streptomycin] and incubated at $38.5^{\circ} \mathrm{C}$ in a humidified atmosphere of $5 \% \mathrm{CO}_{2}$ in air for $15 \mathrm{~min}$ (to facilitate capacitation). Thereafter, sperm were diluted in IVF medium (final density of $1 \times 10^{6} \mathrm{sperm} / \mathrm{mL}$ ). Matured oocytes were transferred to $600 \mu \mathrm{L}$ IVF medium containing sperm for 18-20 h. After IVF, cumulus cells were removed by repeated pipetting, and up to 50 presumed zygotes per group were washed and transferred to 4-well dishes containing $500 \mu \mathrm{L}$ SOF-BE1 medium (Abe et al., 1999) supplemented with $4 \mathrm{mg} / \mathrm{mL}$ fatty acid-free BSA, 5 $\mu \mathrm{g} / \mathrm{mL}$ insulin, $5 \mu \mathrm{g} / \mathrm{mL}$ transferrin, and $5 \mathrm{ng} / \mathrm{mL}$ sodium selenite for 3 days. Presumed zygotes were then cultured until day 8 of embryonic development (day $0=$ day of IVF) in medium of the same composition (free-serum) or in which BSA was replaced by $10 \%(\mathrm{v} / \mathrm{v})$ CDS FBS (serum group). Day 8 expanded blastocysts were used for embryo transfer to recipient host.

\section{Statistical analyses}

Data are presented as mean values standard deviation, except for data reporting changes during embryo development, which are presented as percentages. Each experiment was performed at least three times, and results were analyzed with SPSS (ver. 18.0, SPSS Inc., Chicago, IL, USA). Differences between means were considered significant at $p<0.05$.

\section{RESULTS}

\section{Follicle and oocyte dynamics}

The recovered cumulus-oocyte complexes were morphologically classified into four grades based on the number of cumulus cells layers and homogeneity of the cytoplasm (Table 1). Oocytes number for session was greater in serum groups than those in free-serum groups (29.610.63 vs. $15.6-0.62 ; p<0.05)$. There was no difference in grade $1+2$ mean between serum and free-serum groups ( $2.38 \pm 1.67$ vs. $2.38 \pm 1.48 ; p>0.05)$, but in grade $3+4$ mean between greater in serum group than that in freeserum group (7.31 \pm 7.64 vs. $5.60 \pm 6.29$; $p<0.05)$.

\section{Embryo development rate and the number of blastocysts}

The results regarding the cleaved embryo, as well as the blastocyst development are shown in Table 2. Embryo

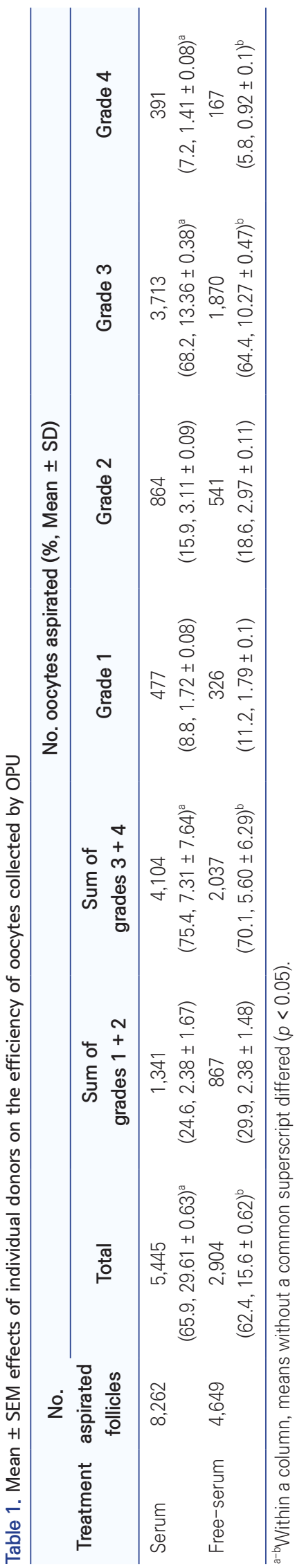


Table 2. Mean \pm SEM effects of individual donors on the efficiency of in vitro embryo production

\begin{tabular}{lccc}
\hline Treatments & $\begin{array}{c}\text { No. of oocytes collected } \\
(\%, \text { Mean } \pm \text { SD per session) }\end{array}$ & $\begin{array}{c}\text { No. cleaved embryos } \\
(\%, \text { Mean } \pm \text { SD per session) }\end{array}$ & $\begin{array}{c}\text { No. of blastocyst developed } \\
\text { (\%, Mean } \pm \text { SD per session) }\end{array}$ \\
\hline Serum & $5,445(65.9,29.61 \pm 0.63)^{a}$ & $3,175(58.3,11.42 \pm 0.42)^{a}$ & $1,802(33.1,6.46 \pm 0.34)$ \\
Free-serum & $2,904(62.4,15.6 \pm 0.62)^{b}$ & $1,802(62.1,9.9 \pm 0.51)^{b}$ & $1,261(43.5,6.78 \pm 0.41)$ \\
\hline
\end{tabular}

${ }^{a-b}$ Within a column, means without a common superscript differed $(p<0.05)$

Table 3. Effects of embryo transfer pregnancy

\begin{tabular}{lccc}
\hline Treatments & $\begin{array}{c}\text { No. embryo } \\
\text { transfer }\end{array}$ & $\begin{array}{c}\text { No. } \\
\text { pregnancy }\end{array}$ & $\begin{array}{c}\text { Pregnancy } \\
\text { rate (\%) }\end{array}$ \\
\hline Serum & 821 & 449 & 54.60 \\
Free-serum & 165 & 93 & 56.30 \\
Total & 986 & 542 & 54.97 \\
\hline
\end{tabular}

cleaved competence rate in free-serum groups was higher than those in serum $(62.1 \%$ vs. $58.3 ; p<0.05$; Table 2$)$. But, blastocyst developmental rate in serum was no difference than that in free-serum $(33.1 \%$ vs. $43.5 \% ; p<0.05)$.

\section{Pregnancy of embryo transfer}

The results regarding the embryo transfer, the number of pregnancy, as well as the pregnancy rate are shown in Table 3. Embryo transfer for 986 recipients. Based on high quality embryo, recipients were allocated into two groups: Group 1, embryo production from serum treatment; Group 2, embryo production from free-serum treatment. Pregnancy rate were result of serum was no difference than that in free-serum $(54.6 \%$ vs. $56.3 \% ; p<0.05)$.

\section{DISCUSSION}

This study aimed to evaluate the suitability of a serumfree culture system for OPU derived bovine embryos. Blastocyst quality is crucial factor to ensure the optimal pregnancy rates following transfer (Rizos et al., 2003). Serum in culture medium plays a role positive embryotrophic factors and inactivation of emryotoxic agents and lead to improve the embryo development, but their mechanism was not determined (Bavister et al., 1995). The effect of serum on lipid metabolism can be due to three mechanisms: (a) lipoproteins present in the serum can be internalized by the cells, increasing the intracellular lipid content (Sate et al., 1999; Abe and Hoshi, 2003), (b) the presence of serum can alter mitochondria and thus b-oxidation of lipids, leading to increased storage of intracellular lipids (Crosier et al., 2001; Abe et al., 2002) and (c) serum could increase neosynthesis of triglycerides by the embryo (Razek et al., 2000). Hatching rate was able to consider to some extent as a measure of embryo quality. To reproduce the culture conditions usually observed after OPU, we compared the impact of the serum-free culture media and serum media on embryos culture. We investigated the development rate of blastocysts, grade of oocytes, recovery of oocytes and number of follicles according for OPU-derived embryo production. The mean number of oocytes obtained by OPU session varies from 7.2 to 20.9.7 (Galli et al., 2001; Su et al., 2012; Jin et al., 2015; Roth et al., 2018), these data agree with our results reported that the average embryo production per donor were 29.6 and 15.6 embryos at sessions, respectively. However, large variations were observed between breeds and donors. Whatever the culture medium, no difference was observed on embryo development. These results are in agreement with two previous reports (Donnay et al., 1997; Ward et al., 2000). The results of embryo transfer were not different between serum and serum free culture medium. In present results indicate that the free-serum culture media was suitable to use for OPU derived embryo production.

\section{CONCLUSION}

In conclusion, we developed the serum-free system for production of in vitro bovine embryos in order to meet the developmental and qualitative requirements for large scale commercial use.

\section{CONFLICTS OF INTEREST}

No potential conflict of interest relevant to this article was reported. 


\section{ACKNOWLEDGEMENTS}

This work was supported by IPET through Agri-Bio Industry Technology Development Program, funded by MAFRA (Grant number: 117029-3 and 315017-5).

\section{AUTHOR'S AFFILIATION, POSITION AND ORCID NO.}

BH Choi, Gyeongsang Nat'l Univ., Researcher, https://orcid.org/0000-0001-9768-1962

BY Park, Gyeongsang Nat'l Univ., Researcher, https://orcid.org/0000-0001-7313-7858

R Kong, Gyeongsang Nat'1 Univ., Researcher, https://orcid.org/0000-0003-4575-1994

MJ Son, Gyeongsang Nat'1 Univ., Researcher, https://orcid.org/0000-0003-1580-6974

CS Park, Gyeongsang Nat'l Univ., Researcher, https://orcid.org/0000-0002-3906-1674

NH Shin, Gyeongnam-do Provincial Government Livestock Research Institute, Ph.D., https://orcid.org/0000-0002-9069-0601

HY Cheon, Gyeongnam-do Provincial Government Livestock Research Institute, Researcher, https://orcid.org/0000-0003-0814-6277

YR Yang, Gyeongnam-do Provincial Government Livestock Research Institute, Researcher, https://orcid.org/0000-0002-7699-0923

JW Lee, Gyeongnam-do Provincial Government Livestock Research Institute, Director, https://orcid.org/0000-0001-9001-7858

JI Jin, Gyeongsang Nat'1 Univ., Ph.D., https://orcid.org/0000-0002-5790-7637

IK Kong, Gyeongsang Nat'1 Univ., Professor, https://orcid.org/0000-0002-1906-9898

\section{REFERENCES}

Abe H, Hoshi H. 2003. Evaluation of bovine embryos produced in high performance serum-free media. J. Reprod. Dev. 49:193-202.

Abe H, Yamashita S, Itoh T, Satoh T, Hoshi H. 1999. Histochemical and ultrastructural evaluations of cytoplasmic lipid droplets in bovine embryos cultured in serum-free and serum-containing media. Theriogenology 51:232.

Abe H, Yamashita S, Satoh T, Hoshi H. 2002. Accumulation of cytoplasmic lipid droplets in bovine embryos and cryotolerance of embryos developed in different culture systems using serumfree or serum-containing media. Mol. Reprod. Dev. 61:57-66.

Bavister BD. 1995. Culture of preimplantation embryos: facts and artifacts. Hum. Reprod. Update. 1:91-148.

Crosier AE, Farin PW, Dykstra MJ, Alexander JE, Farin CE. 2001. Ultrastructural morphometry of bovine blastocysts produced in vivo or in vitro. Biol. Reprod. 64:1375-1385.

Donnay I, Van Langendonckt A, Auquier P, Grisart B, Vansteenbrugge A, Massip A, et al. 1997. Effects of co-culture and embryo number on the in vitro development of bovine embryos. Theriogenology 47:1549-1561.

Farin PW, Crosier AE, Farin CE. 2001. Influence of in vitro systems on embryo survival and fetal development in cattle. Theriogenology 55:151-170.

Galli C, Crotti G, Notari C, Turini P, Duchi R and Lazzari G. 2001. Embryo production by ovum pick up from live donors. Theriogenology 55:1341-1357.

Goto K, Kajihara Y, Kosaka S, Koba M, Nakanishi Y, Ogawa K. 1988. Pregnancies after co-culture of cumulus cells with bovine embryos derived from in-vitro fertilization of in-vitro matured follicular oocytes. J. Reprod. Fertil. 83:753-758.

Holm P, Booth PJ, Schmidt MH, Greve T, Callesen H. 1999. High bovine blastocyst development in a static in vitro production system using SOFaa medium supplemented with sodium citrate and myo-inositol with or without serum-proteins. Theriogenology 52:683-700.

Jacobsen H, Schmidt M, Holm P, Sangild PT, Vajta G, Greve T, et al. 2000. Body dimensions and birth and organ weights of calves derived from in vitro produced embryos cultured with or without serum and oviduct epithelium cells. Theriogenology 53:1761-1769.

Jin JI, Choi BH, Kim SS, Park BY, Lee JG and Kong IK. 2015. Possibility of Repeated Use of Elite Donor Cows for Mass Production of OPU-Derived Embryos. J. Emb. Trans. 30:149159.

Lane M, Gardner DK. 2007. Embryo culture medium: which is the best? Best Pract Res Clin Obstet Gynaecol 21:83-100.

Lonergan P, O'Kearney-Flynn M, Boland MP. 1999. Effect of protein supplementation and presence of an antioxidant on the development of bovine zygotes in synthetic oviduct fluid medium under high or low oxygen tension. Theriogenology 51:1565-1576.

Lonergan P, Rizos D, Gutie'rrez-Ada'n A, Moreira MB, Pintado B, de la Fuente J. 2003. Temporal divergence in the pattern of messenger RNA expression in bovine embryos cultured from the zygote to blastocyst stage in vitro or in vivo. Biol. Reprod. 69:1424-1431.

Lonergan P, Rizos D, Ward F, Boland MP. 2001. Factors influencing oocyte and embryo quality in cattle. Reprod. Nutr. Dev. 41:427-437.

Lu KH, Gordon I, Gallagher M, McGovern H. 1987. Pregnancy established in cattle by transfer of embryos derived from in vitro fertilisation of oocytes matured in vitro. Vet. Rec. 121:259-260.

Mesalam A, Kong RM, Khan I, Chowdhury MMR, Choi BH, Kim 
SW, Cho KW, Jin JI, Kong IK. 2017. Effect of charcoal:dextran stripped fetal bovine serum on in vitro development of bovine embryos. Theriogenology 17:312-319.

Murakami M, Dong YJ, Suzuki T, Taniguchi M, Kaedei Y, Sato Y, Tanihara F, Otoi T. 2011. Development and subsequent cryotolerance of domestic cat embryos cultured in serum-free and serum-containing media. Cryobiology 63:170-174.

Pinyopummintr T, Bavister BD. 1994. Development of bovine embryos in a cell-free culture medium: effects of type of serum, timing of its inclusion and heat inactivation. Theriogenology 41:1241-1249.

Razek IAE, Charpigny G, Kodja S, Marquant-Leguienne B, Mermillod P, Guyader-Joly C, et al. 2000. Differences in lipid composition between in vivo- and in vitro-produced bovine embryos. Theriogenology 53:346.

Rizos D, Gutierrez-Adan A, Perez-Garnelo S, De La Fuente J, Boland MP, Lonergan P. 2003. Bovine embryo culture in the presence or absence of serum: implications for blastocyst development, cryotolerance, and messenger RNA expression. Biol. Reprod. 68:236-243.

Roth Z, Inbar G and Arav A. 2008. Comparison of oocyte developmental competence and follicular steroid content of nulliparous heifers and cows at different stages of lactation. Theriogenology 69:932-939.

Sata R, Tsujii H, Abe H, Yamashita S, Hosh H. 1999. Fatty acid composition of bovine embryos cultured in serum-free and serum-containing medium during early embryonic development. J. Reprod. Dev. 45:97-103.

Su L, Yang S, He X, Li X, Ma J, Wang Y, Presicce GA and Ji W. 2012. Effect of donor age on the developmental competence of bovine oocytes retrieved by ovum pick up. Reprod. Domest. Anim. 47:184-189.

Thompson JG, Mitchell M, Kind KL. 2007. Embryo culture and longterm consequences. Reprod. Fertil. Dev. 19:43-52.

Van Langendonckt A, Donnay I, Schuurbiers N, Auquier P, Carolan C, Massip A, et al. 1997. Effects of supplementation with fetal calf serum on development of bovine embryos in synthetic oviduct fluid medium. J. Reprod. Fertil. 109:87-93.

Ward FA, Lonergan P, Enright BP, Boland MP. 2000. Factors affecting recovery and quality of oocytes for bovine embryo production in vitro using ovum pick-up technology. Theriogenology 54:433-446.

Wirthensohn K, Barth CA. 1985. Influence of hormones and growth factors on viability, DNA, and protein content of adult hepatocytes in primary culture. In Vitro Cell Dev. Biol. 21:546-552.

Wrenzycki C, Herrmann D, Lucas-Hahn A, Lemme E, Korsawe K, Niemann H. 2004. Gene expression patterns in in vitroproduced and somatic nuclear transfer-derived preimplantation bovine embryos: relationship to the large offspring syndrome? Anim. Reprod. Sci. 82-83:593-603. 